\title{
The global crisis and the implications for developing countries and the BRICs: Is the " $B$ " really justified?
}

JAN KREGEL*

Developing countries experienced high growth and low inflation in the new Millennium. This has been due in part to the impact of the expansion in developed country financial markets on demand for exports. Especially positive has been the performance of the so-called BRICs - Brazil, Russia, India and China. The collapse of the financial markets will eliminate the positive impact of export-led growth. An alternative strategy will be required. One possibility is to build on domestic sources of demand. Brazil is well-placed to engage in such a strategy and already has a number of policies to support this alternative. They should be introduced rapidly.

Keywords: Export-led growth; financial crisis and development; BRICs; national development strategies.

JEL Classification: 011; 016; 023; 024; 010; 019.

The New Millennium has been characterized by exceptionally positive performance for most developing economies. Even excepting India and China, performance in Latin America and Africa has been higher and more sustained that in any period since the post-war golden age of late import substitution.

Growth rates continued to increase after the turn of the century on a sustained basis (see Figure 1).

Perhaps even more important in the perception of good performance in the period was that positive growth performance was accompanied by a generalized reduction in consumer prices to low and persistently stable levels (see Figure 2):

But, even more important was the elimination of the external constraint on

\footnotetext{
* Levy Economics Institute of Bard College. E-mail: jankregel@yahoo.com. Revised draft of a paper prepared for the XXI Forum Nacional, Opening Session: The New Role of the BRIMCs and the Global Crisis, Rio de Janeiro, $18^{\text {th }}$ May 2009.
} 
Figure: 1

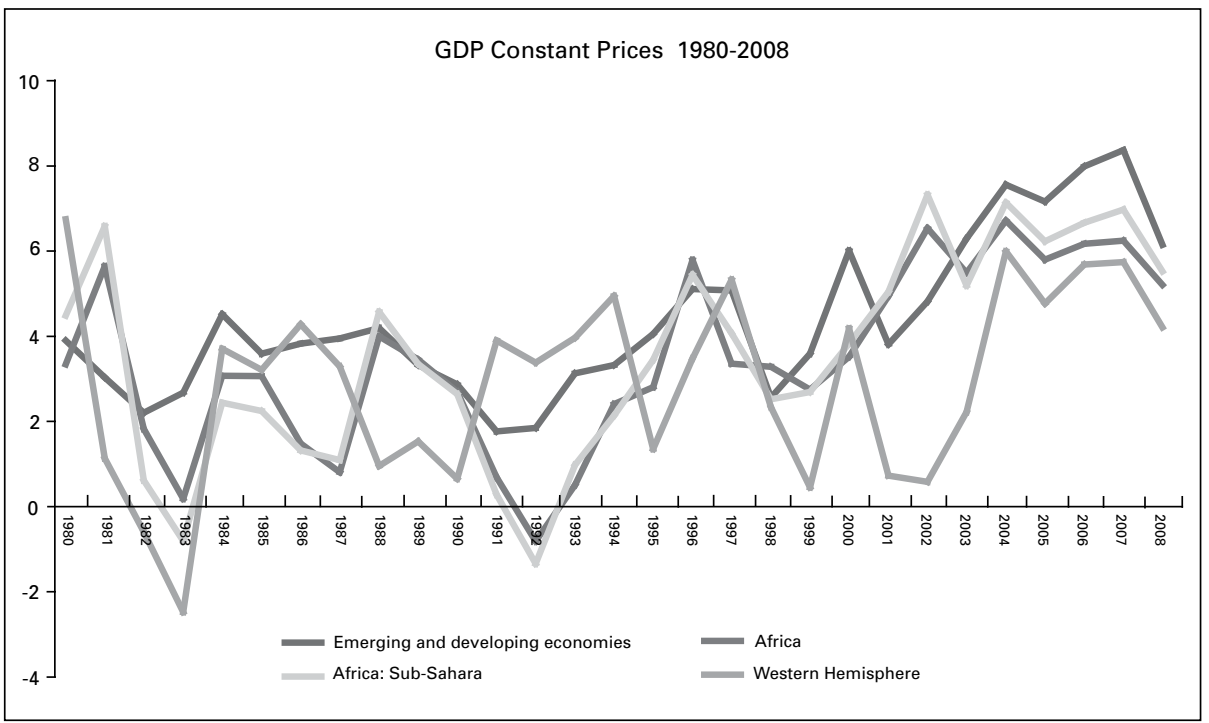

Figure: 2

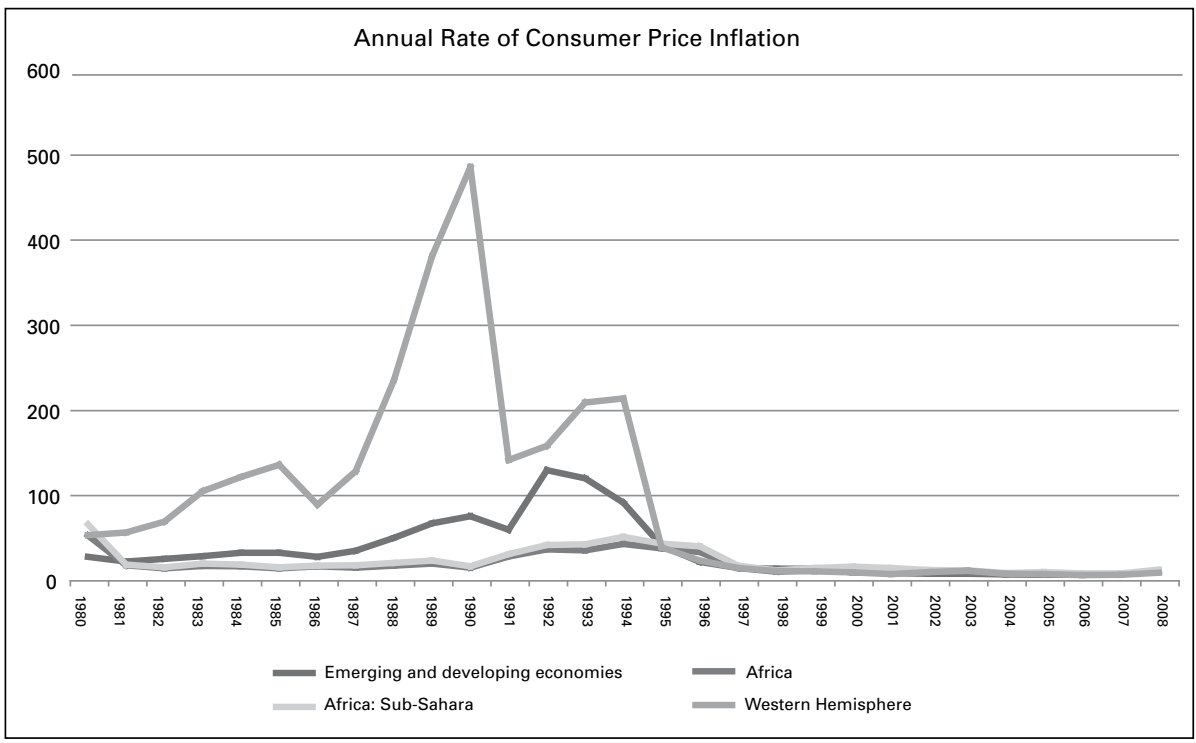


Figure: 3

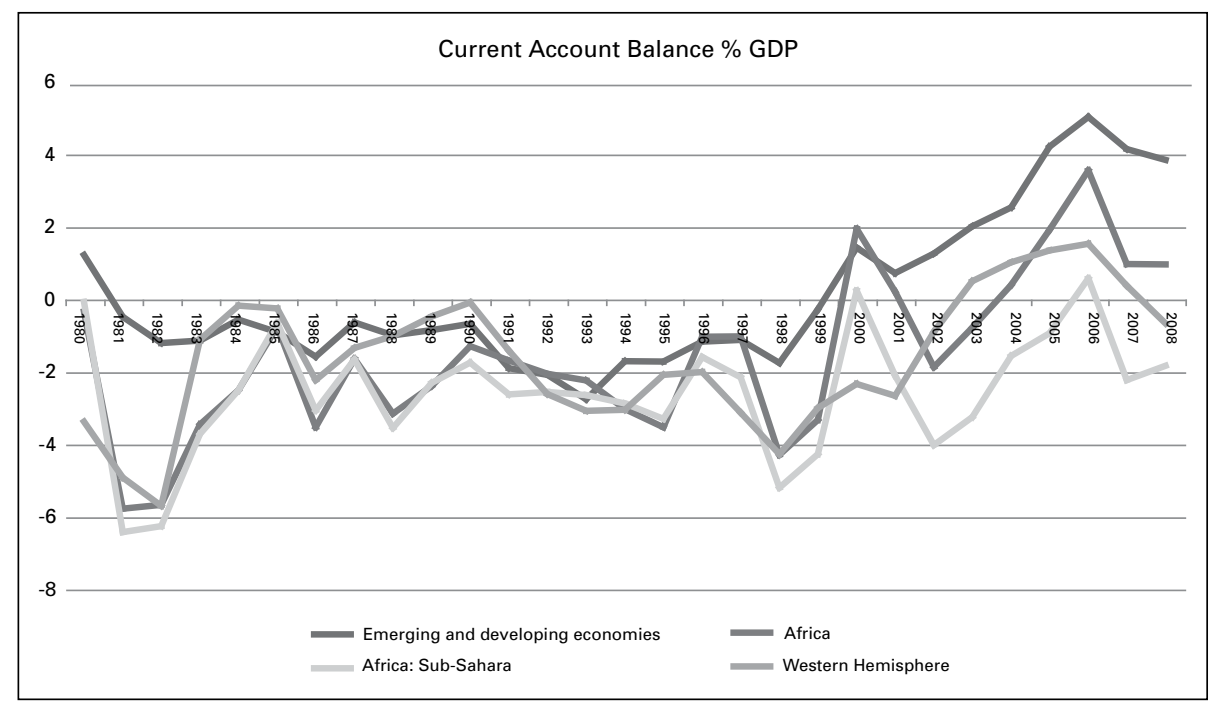

Source: IMF World Economic Outlook Database April 2009

growth in developing countries as virtually all of the non-Asia developing world managed to generate current account surpluses. It was these current account surpluses that fed the increased in foreign exchange reserves that had already been observed in the recovering Asian economies, and in particular in China (see Figure 3).

Thus, the answer to the question of the impact of the current financial crisis on developing countries in general and the BRICs in particular depends on the source of this sharply increased in growth and external accounts in the developing world. One possibility is that structural adjustment policies brought about these improvements, in which case, these countries should be relatively immune from the current turmoil in financial markets.

The alternative is to look at the counterpart of these improvements in the changed in policy that were introduced in the US in the 1990s which led to the massive increase in global trade and global imbalances. In simple terms, the US forced the rest of the world to convert to policies of export-led growth. There were four basic forces driving global trade in the period. Virtually all of them were linked to changes in financial regulation and competition in the US. The first was the impact of private equity firms in driving US firms to increase rates of return - either in defence or as a result of a takeover by private equity investors many US firms were driven to outsource production to take advantage of lower foreign labour costs linked to US technological dominance. This tended to put downward pressure on US wages and employment. Part of the response was the increase in household borrowing to preserve consumption in the presence of falling real wages. This was a process that was in place long before the advent of sub-prime mortgages, but was certainly accelerated by the upward impetus this created on house prices and thus 
on the ability of households to use their home equity as an ATM and providing for rising demand for the exports of developing countries, often produced by US companies operating abroad. The third was the creating of the so-called shadow banking system, but in reality the force at work was the increase in leverage that allowed large increases in international capital flows, many to developing countries, joining current account surpluses to support exchange rates and further increase foreign reserves. The final factor was the emergence of real return investment that turned primary commodities into an asset class. The investments in commodity investment funds helped to accelerate the rise in commodity prices that had commenced with the rapid growth of some developing countries. This rise in commodity and petroleum prices produced rapid increases in the terms of trade which again reinforced the rising incomes in developing countries.

Now, it seems clear that all of these factors were driven by the evolution of financial conditions in the US. Thus I have characterized the evolution of developing countries in the New Millennium as a "bubble", for if the US economy was experiencing a financial bubble the counterpart of that bubble was the extremely beneficial conditions in developing countries and in particular in Latin American emerging markets. It would thus be prudent to conclude that if the crisis will lead to a permanent elimination of leverage in the US system at levels similar to recent years, if households move to pay down debt and increase savings, and if the measures to bring manufacturing employment back to the United States, that we cannot foresee a return to the extremely positive conditions experience by developing countries in the recent past.

However, it has become common to distinguish certain emerging market economies from developing economies in general and to suggest that their behavior will be quite different. I have always considered the definition of emerging market economies to have been created by sell-side investment firms. It related to countries emerging from default and thus once again potential investment destinations. The origin was in the emergence of Latin American countries after the 1980s debt crisis and linked to the Brady bond solution: finding alternative lenders who would bail out the banks' syndicated loans. These alternative lenders were institutional and other portfolio investors, and the generalized opening of financial markets and the privatization of state assets that accompanied it were designed to provide alternative assets for them to buy. Washington Consensus policies provided the expectations of above market returns. The result of this combination, as we now know was to produce price stability, slower growth, as well as periodic financial crises in which most of that growth was reversed. Emerging markets have only been a clear success for those developed country financial institutions that intermediated this process.

It has also become common to distinguish a small number of emerging market economies - the so-called BRICs mentioned in the title of this session. But this 
category is also an invention of developed country financial institutions ${ }^{1}$ seeking similar intermediation profits. Initially the BRICs were a class of middle-income emerging market economies of relatively large size capable of more or less self-sustained expansion. At their baptism it was predicted that they would comprise more than $10 \%$ of global output by 2010 , but by the end of 2007 the BRICs already accounted for $15 \%$ of the global economy. But the real interest was not in their income growth, or even per capita income growth, but in the performance of their financial markets, and in particular their equity markets. Thus most importantly is the increase in equity markets between 2001 and 2007 Brazil has risen by $369 \%$, India by $499 \%$, Russia by $630 \%$, and China by $817 \%$ based on the Hang Seng China Enterprises Index.

The inclusion of Mexico in the group to form the BRIMCs seems however to have been due more to the exigencies of political discussion of governance reform at the Fall 2006 Bank-Fund meetings in Singapore ${ }^{2}$ than to economic performance, although this was good by recent standards at 3.9 percent compared to 4.6 percent for Brazil from the 2004-2007 period and 2.6 percent compared to Brazil's 3.4 percent from the 2001-2007 period. The political as distinct from economic nature of this inclusion may be seen from the fact that Mexico differs from the original grouping, first by being a member of the OECD, and thus not technically a developing country, and second by not being large or self-sufficient, economically dependent on the US through NAFTA. Indeed, Mexico was included in the N-11 Goldman Sachs grouping of countries that would catch up with the G-7, but not with the BRICs. ${ }^{3}$

Nonetheless, the important point is all of these numerical arrangements were formed on the wave of the exceptional rapid recovery from Asian financial crisis and the dot.com equity market collapse in developed countries, and particularly in Latin America, which did not experience any major financial crisis in the new Millennium. Indeed, the original formulations were admitted to have been based on dreams, dreams that may have been transformed into nightmare by the global financial crisis and the threat of a global depression. It raises questions in three areas: how the BRICs and other emerging market countries will be impacted by the

\footnotetext{
${ }^{1}$ O’Neill, J.,"Building Better Global Economic BRICs," Global Economics Paper 66, Goldman Sachs, Economic Research Group, 2001.

2 "This weekend, Mexico will be included in the BRIMCs Group, comprising the six most important emerging nations in the global economy that will complement the decisions of the Group of Seven (G7) in which the United States, Germany, France, Italy, Japan, the United Kingdom and Canada participate. [...] The extended talks will not only concern the way multilateral trade talks can be reestablished after the failure of the Doha talks but also involve multilateral coordination mechanisms for reducing global imbalances, supporting the medium/term reform of the International Monetary Fund (IMF) and restructuring the governing bodies of both the IMF and the World Bank (WB).” El Financiero/Alicia Salgado/Envoy/Singapore, http://fox.presidencia.gob.mx/en/goodnews/?contenido=27161\&pagina=2.

${ }^{3}$ The developing country political grouping with more potential impact on the global economy is the equivalent of the developed country trilateral: IBSA including South Africa, India and Brazil, that aims to increase South-South cooperation. See http://www.ibsa-trilateral.org/.
} 
crisis, what role they may play in responding to it and the impact that they might have on the institutional changes in the international financial system.

\section{THE IMPACT OF THE CRISIS}

In assessing the impact of the crisis it is important to note that the BRICs grouping was not based on economic similarities. Indeed, the four original BRICs could not be more different. It is tempting however to divide them into two subgroups. Two countries, India and China, are still peasant economies with relatively closed, state controlled and regulated capital markets, while the other two, Brazil and Russia are still primarily natural resource based economies, open to foreign trade and financial flows, with mixed state-private sector controls of capital markets. The former group has guided exchange rates, greater in China than in India, while the latter has more flexible exchange rates. The former group practices development strategies based on domestic industrialization for export, through manufacturing or services, while the latter two follow strategies guided by international comparative advantage to determine exports in directing productive structure. The latter group has past experience of exchange rate and financial crises, usually accompanied by high inflation, former do not. The latter have been borrowers from the IMF and have employed structural adjustment policies to access IMF funding while the former have not.

However, in all, the government plays a role in guiding the economy and plays a role in directing capital markets. The basic difference in this regard is Brazil, where this role is played by the National Development Bank, BNDES, an institution that is formally independent of the private capital market, or better, supplants the existence of a private capital market. All countries have benefited directly or indirectly from the expansion of the United States economy over the last two decades at rates that were above what was once considered sustainable and compatible with price stability, and also from the international imbalances that have been for some time above what most experts considered as sustainable or could be financed with a stable dollar exchange rate.

It is also important to note that as in all other global statistical comparisons, whether they be poverty reduction or pollution, they are skewed by the weight of China and to a lesser extent India in the calculations. If China and India were to grow by Brazil's average growth rate over the last ten years, the forecasts of catching up would not be so impressive. Indeed, Goldman Sachs has recently raised the question of "Can we, for example, justify the B in BRICs?".

Since the initial impact of the current crisis was in the financial sector, and in particular the freezing of domestic liquidity in industrialized countries, and then globally, followed by deleveraging and a sharp decline in lending to private productive enterprises and consumers, the analysis should start with the impact on the financial systems in the BRICs.

Since the liquidity crisis and the failure of financial institutions led to the reces- 
sion in the United States, which then spread to the other industrialized economies, the European Union and Japan, the second question that has to be considered is the impact of the slowdown in industrialized countries on global trade and in particular on the performance of the emerging markets countries and the BRICs. This impact highlights the fact that the exceptional growth performance of these countries has been due to the influence of globalization on trade and financial conditions. The performance of the BRICs must thus be considered in the global context as none of them seems to possess the internal engine of growth required to fulfill the dream growth scenarios.

This division follows the evolution of the current crisis that has been two dimensional. The first dimension was the relatively contained difficulties in the US subprime mortgage market, that spread to the entire US financial system and then to Europe. It has called into question the very operation of the spread trading model based on large leverage in industrialized country financial institutions. In reality, the difficulty was not so much the extension of the model to low income borrowers as it was the need for high volume to profit from extremely small spreads. The only way that this could be achieved was through increased reliance on short-term funding and on high levels of leverage. This was especially evident in the so-called shadow banking system that provided much of the leverage to the system. These institutions borrowed short to invest in longer term assets without the benefit of either FDIC insurance for the lenders or of access to the Fed's discount window for lender of last resort funding. These institutions have all become insolvent and will not return in the immediate future and thus neither will the leverage that they provided. The second source of leverage was through the use of derivatives which allowed market exposure against the payment of negligible margin payments. They also implied substantial credit exposure in the form of counterparty risk, but this was not recognized until the crisis broke out. These instruments will also be under much tighter restrictions and margin requirements. Thus, the two basic aspects of the financial crisis will be the loss of return to financial institutions due to rising capital requirements and the reduction in leverage. This process of deleveraging will be accompanied by a parallel process of reduction in asset prices, the deflation of the so-called asset bubbles.

This is the basis for the current stalemate in policy responses and in the lending behaviour of banks. If the liquidity crisis is the result of deleveraging, and leverage was the cause of the rise in asset prices, then it is possible to conclude that the recent decline in asset prices is not due to market valuations but simply to the lack of liquidity preventing efficient markets from providing appropriate pricing. Solving the liquidity crisis then allows prices to return to "normal" and a strengthening of bank balance sheets that will allow them to lend once again.

This point of view may be seen in a report from one of the largest fixed income asset managers in the US:

"The deleveraging of the shadow banking system has set 'pawn shop' prices on many otherwise high-quality securities. This is the result 
of the liquidity premium that is being demanded by buyers who have the available balance sheet to take on even the high-quality securities that deleveraging investors are forced to sell. The prices in the market are not indicative of the long-term value of many of the high-quality securities in the market. We could call this the risk premium for a shortage of balance sheet in the market, or a liquidity premium. [...] However, since the Treasury, the Fed and the FDIC (Federal Deposit Insurance Corporation) do not want securities to trade at the pawn shop bid level, they have developed programs intended to support prices, such as the Commercial Paper Funding Facility (CPFF) and the Term Asset-Backed Securities Loan Facility (TALF). With the TALF, the Treasury and the Fed are effectively stepping around the banking system to create a sort of government shadow bank to provide financing for asset-backed securities (ABS). The government is substituting its own balance sheet for the missing balance sheet on Wall Street, with the aim of supporting prices on $\mathrm{ABS}$ and incrementally nudging the prices up closer to their intrinsic value."

Alternatively, if the assessment is that the liquidity currently provided by the government programmes will never be provided by private sector institutions, then deleveraging will provide for a permanent decline in asset prices and bank profitability. The problem with assets prices is not the lack of liquidity providing pawn shop prices, but simply that the leverage provided Carnival prices and the losses will have to be born either by the government or by the private sector financial institutions. In either case, the liquidity machine based on SIVs, margined positions and default insurance will not be part of the new financial system.

There are thus two basic impacts on BRICs financial systems. The first is the question of intrinsic value prices. Although financial institutions had holdings of US issued asset backed securities, their holdings were not substantial and for Chinese and Indian banks is reported in the 100s of millions, rather than billions of losses. Russia and Brazil also appear not to have made substantial investments in the types of securities that will be impacted by deleveraging deflation of prices. Thus, deleveraging and asset price deflation should not have a major impact on the surety of BRICs banking systems.

However, the high levels of liquidity had additional impacts on prices. In particular, it is now generally accepted that the run up in petroleum and primary commodity prices since 2004 have been driven by developed country financial institutions' proprietary speculative trading, as well as by the sales to institutional investors of so-called "real return" investments as hedges against inflation. Thus, these commodities came to be considered an asset class, and entered investment funds, but given the difficulty of storage, with positions determined by purchase of futures contracts. It is not surprising that once deleveraging started the prices in these markets quickly collapsed. 
The second impact of the high levels of liquidity, coupled by the response of the US central bank to the collapse of the dot com equity bubble and the subsequent political turmoil in September 2001 to keep interest rates at historically low levels, made the Goldman Sachs dreams into reality as capital flowed to BRICs equity markets. Brazil for several years had the highest total returns on equities of any country in the world. Coupled with the rise in petroleum prices, the shift to biofuels, and the rise in food and commodity prices, led to massive capital inflows that the central bank was unwilling to offset, producing a very rapid rise in the effective exchange rate. At the same time, the unwillingness to offset the monetary tightening caused by the appreciation with lower interest rates led to extremely high interest rate differentials. The real became a large positive carry currency, producing substiantial short-term speculative interest arbitrage inflows. ${ }^{4}$

The combination of these factors produced a rising current account surplus in the presence of real exchange rate appreciation, rising asset prices and improvements in the terms of trade that translated into higher incomes and higher growth rates. It was enough to justify the B in BRICs.

However, for the rising number of Brazilian export firms the appreciation of the real was a mixed blessing, and many sought to temper the impact on their external competitiveness and profitability by hedging against a further decline in the US dollar. In addition many banks that had profited from the 1999 exchange rate crisis by using derivatives to speculate against the currency now reversed their strategy on the belief that the trend in capital flows and external balance would continue, leading to sustained strength in the currency. Thus, instead of using futures contracts to speculate on a depreciation after the 1998 election, banks took positions to profit from the continued strength of the currency as forecasts predicted a return to parity with the dollar, writing out of the money call options on the dollar, writing target forward contracts for corporate clients and arranging low interest rate dollar lending.

Of course when the exchange rate started its rapid decline in the beginning of 2008 many corporate buyers of these contracts could not make payment. It is es-

\footnotetext{
${ }^{4}$ This position has been maintained through the crisis: "Borrowing US dollars at the three-month London interbank offered rate of 1.13 percent and using the proceeds to buy real and earn Brazil's three-month deposit rate of 10.51 percent rate would net an annualized 9.38 percent, as long as both currencies remain stable". The same is true for many of the BRICs and other developing countries: Goldman Sachs recommended on April 3 that investors use euros, dollars and yen to buy Mexican pesos, real, rupiah, rand and rubles from Russia, where the benchmark central bank rate is 13 percent. "Using equally weighted baskets, that carry trade would have returned 8 percent in the past month, for an annualized 165 percent, data compiled by Bloomberg show. Group-of-three currencies are expensive while emerging-market currencies are cheap", said Themos Fiotakis, a London-based Goldman Sachs analyst. "The downside risks have declined significantly for emerging-market currencies. Even if these currencies remain flat, the carry is still attractive." Cf. Kim-Mai Cutler \& Bo Nielsen, "Carry Trade Comeback Means Biggest Gains Since 1999 (Update2),” April 14, 2009, http://www.bloomberg. com/apps/news?pid=newsarchive\&sid=aKbFuB4RIpQo.
} 
timated that outstanding corporate exposure to these derivatives was between $\mathrm{R} \$ 49-74$ billion.

It is reported that Sadia, a food processor, Votorantim, an industrial conglomerate, and Aracruz, one of the world's biggest paper and pulp manufacturers, among others have reported heavy losses on currency derivatives. The possibility that hundreds of companies may wish to renegotiate their exposure to derivatives with issuing banks prompted provisional measure MP443 which made provision for government controlled Banco do Brasil and Caixa Econômica to acquire capital of private financial institutions. The MP also creates an investment bank under CEF to acquire capital not just in the financial, but other sectors that could extend to construction companies. It also authorized the Central Bank of Brazil to put in place currency swap lines with other international central banks to increase the potential to provide liquidity to the market. It has also been suggested that Itaú merged with Unibanco in order to protect the smaller bank from its impending losses on derivatives contracts written to corporate clients. Votorantim acquired Aracruz in order to meet the derivatives losses of the latter, and Banco do Brasil has acquired a 50 percent stake in Bank Votorantim and also acquired a near three-quarters share of Nossa Caixa. Overall, estimates are that the eight largest Brazilian banks will take losses on excess of $\mathrm{R} \$ 5$ billion as a result of their own positions or counterparty failures.

Thus, although the banks themselves apparently did not engage in the same kinds of originate and distribute activities as US banks, or investment in these assets to gain higher yields, the indirect impact through the exchange rate appreciation and rising asset prices produced conditions which were typical of prior crises, creating interest rate differentials that made short dollar positions attractive, and these were primarily pursued through derivative positions for their own book or to provide accommodation to their corporate clients. These activities were not sufficient to threaten the stability of the financial system, although a number of preventive merger actions were undertaken to ensure this result.

One of the reasons for this result is certainly the more rigorous regulation of derivatives markets in Brazil. However, those who argue that it was primarily due to the prudent management of bank balance sheets seem to overstate the case. The primary incentive for the development of securitized lending and the sale of securitized asset back securities in industrialized financial markets was the low profitability of commercial banking relative to investment banking, and the search for yield by investors facing extremely low or negative domestic rates.

The interest rate policies of the central bank and the impact on the government financing requirement even in conditions of primary surplus meant that Brazilian banks had no need to reach for yield by increasing risks. Globally higher returns at zero risk were available in government securities and there was thus little need to move into mortgage backed securities issued abroad. Returns on equity for Brazilian banks over the sub-prime period have been roughly double the figure 
for the United States and substantially higher than in other BRIC countries. In addition such dollar-denominated structured investments were increasingly risky given the trajectory of the exchange rate.

Bank Return on Equity

(In percent)

\begin{tabular}{lccccccc}
\hline & 2003 & 2004 & 2005 & 2006 & 2007 & 2008 & Latest \\
\hline Brazil & 21.1 & 22.1 & 29.5 & 27.3 & 28.9 & 20.4 & October \\
Russia & 17.8 & 20.3 & 24.2 & 26.3 & 22.7 & 12.1 & September \\
China & $\ldots$ & 13.7 & 15.1 & 14.8 & 19.9 & $\ldots$ & June \\
India & 18.8 & 20.8 & 13.3 & 12.7 & 13.2 & 12.5 & March \\
Japan & -2.7 & 4.1 & 11.3 & 8.5 & 6.1 & 3.0 & September \\
\hline United States & 15.0 & 13.2 & 12.7 & 12.3 & 7.8 & 3.3 & September \\
\hline
\end{tabular}

Source: Table 27 Statistical Appendix Global Financial Stability Report, IMF, April 2009.

Nonetheless, banks and corporates saw little difficulty in running exchange rate risks through derivative contracts and inappropriate hedging vehicles.

More important than the impact of the US financial expansion on asset prices was on the creation of global liquidity. The improvement in the exchange rate was largely due to sharply increased foreign direct investment flows, reinforced by short-term carry trade speculation and the attractiveness of Brazilian equities. As noted above, most of these fatal attractors for capital inflows were driven by the leverage created in the US financial system. Even the impact on commodities prices that was presumed to be caused by rising consumption in China was in the end financed by borrowing by the American consumer, financed by the housing boom.

The reversal of this process through deleveraging not only brought the asset and commodity bubbles to an end but also required US financial institutions to repatriate capital to meet losses and close positions. European banks that had used cheap dollar borrowing to finance high yield mortgage backed assets faced a similar problem, producing a dollar scarcity that brought a capital reversal similar to the 1990s crises and a sharp reversal of the appreciation of emerging market currencies.

The result of the dollar shortage was a global liquidity crisis that was similar to that experienced in the summer of 1998 after the Russian and LTCM crisis.

This reversal of international capital flows and the evaporation of dollar liquidity that produced the contagion of the crisis to emerging markets and developing countries as global trade ground to halt. Falling demand for imports throughout the world coupled with the disappearance of trade finance to spread the collapse in demand in the US and Europe throughout the developing world. 
World exports 2005-09 (in current US billion dollars)

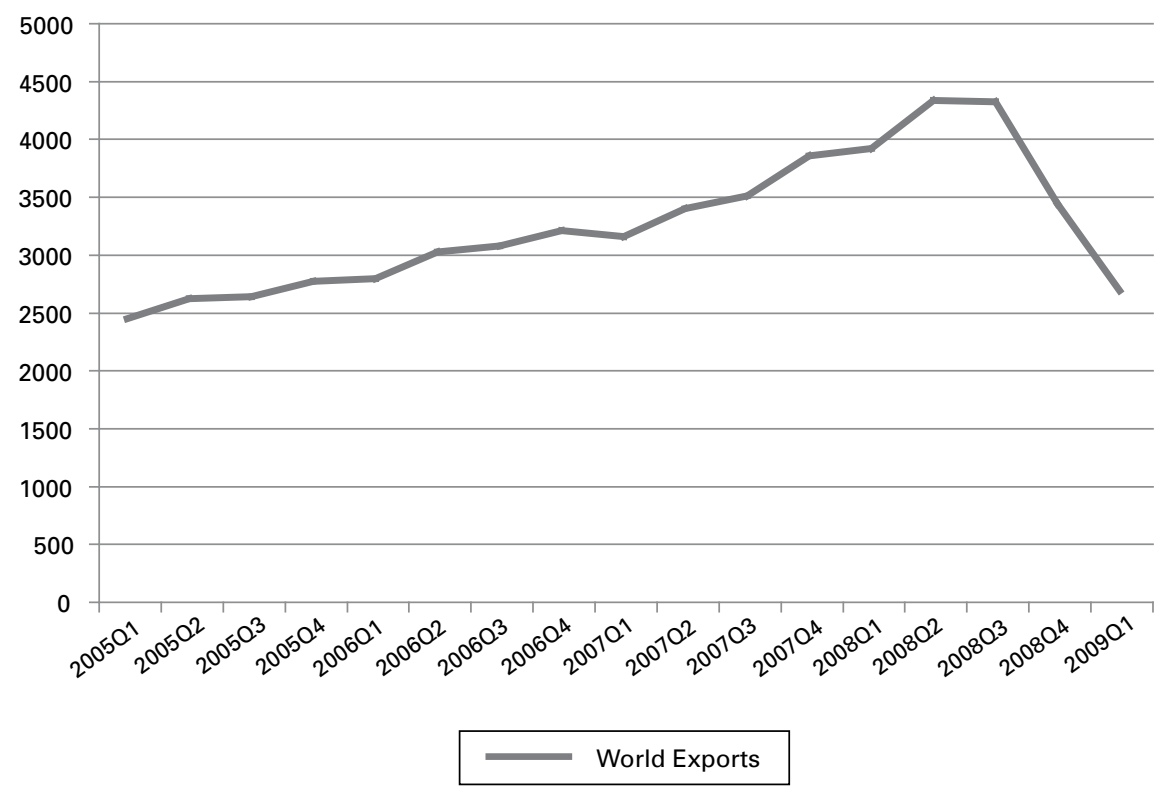

Source: World Trade Organisation.

\section{Brazilian Exports 1977-2008 \$ million}

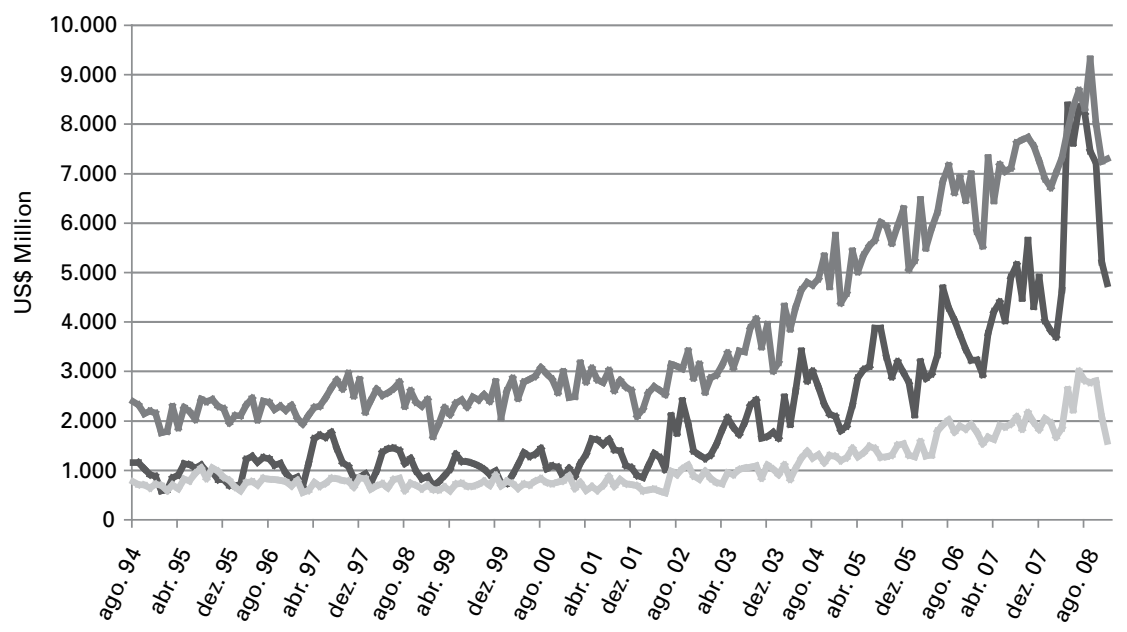

\footnotetext{
2947 - Exportações - Produtos básicos - US\$

2974 - Exportações - Produtos semimanufaturados - US\$

3001 - Exportações - Produtos manufaturados - US\$
}

Source: IPEA Online Database. 
Thus, virtually all of the positive performance that led to achieving the Brazilian dream of meeting the target of the BRICs appear to be linked to a financial model and financial flows that is not likely to be reestablished. The degree of leverage that had become normal in developed country financial institutions will not return, the leverage generated by financial derivatives will now be couched in much stronger margin requirements. This will not only mean lower asset prices but lower global demand for emerging market exports and thus reduced financial flows to emerging markets including the BRICs.

\section{THE RESPONSE TO THE CRISIS}

As noted above, there are two possible responses to the crisis. One involves an attempt to restore the status quo and the alternative, recognition that the structural changes that are likely to occur in developed country financial market structure mean that is cannot be done. The former requires little more than a survival policy, to wait until prices return to intrinsic values and the US government can withdraw its balance sheet support and return the management of the financial system to the forces of the market. Brazil and the other BRICs seem well placed to carry out such a policy, given that their financial systems have been relatively untouched by crisis and the high levels of foreign reserves available to cover temporary external deficits caused by the decline in global trade. The Brazilian banking system has not been impaired by the crisis, indeed mergers may have strengthened its ability to meet the crisis, and reserves of around $\mathrm{R} \$ 200$ billion plus Fed swap lines and IMF support are certainly sufficient to allow for a recovery period of 6 to 12 months, which fits the scenario of those who are predicting recovery by the end of the year.

The alternative scenario raises the question of who will provide the capital and the demand that will allow growth in Brazil to continue at a rate above 3 percent if conditions do not, indeed cannot, return to normal because of structural changes in US households' propensity to consume and the disappearance of leverage from the global financial system. Here there is general similarity across all BRIC economies for they all depend on expanding demand through increasing global trade and global imbalance financed by global financial flows. China retains greater autonomy compared to the others given the size and permanence of its foreign exchange reserve position. Indeed, if China decides to replace the lost global demand by increased domestic expansion and follows through on its policy to diversify its reserve holdings by increasing its purchase and stockpiles of natural resources it may provide the source of Brazil's external demand. There are already signs of domestic demand recovery in China that would drive demand for primary materials, and there is clear evidence that the Central Bank has chosen to diversify its reserves holdings in natural resources rather than in currency diversification. However, it is unlikely that China can provide sufficient internal stimulus to replace the US on a global scale, the impact of its reserve diversification process on commodity inflation would provide a stimulus to inflation that might be cut off by central bank decisions 
to reduce stimulus packages and increase interest rates before the global economy begins to recover.

Thus China provides a temptation to return to the Brazilian development strategy of the 1990s and 2000s of designing policies to attract external capital and build on external demand. However, if the shape of globalization and the structure of global demand are changed by the crisis this policy would be a mistake.

This temptation to wait for a return to the conditions of the last decade is also reinforced by the return of external capital inflows. But these have been driven primarily by the expectation of a return to previous growth rate and the resumption of the emerging market carry trade, now being touted by US investment banks. A Bloomberg news story noted that "Last month, the carry trade roared back, with ABN Amro's index gaining 4.6 percent, its best month since September 2003. As of today, the Dollar Index had fallen about 5.4 percent from its March 4 high. An equally weighted basket of currencies consisting of Turkish lira, Brazilian real, Hungarian forint, Indonesian rupiah, South African rand and Australian and New Zealand dollars - bought with yen, dollars and Euros - earned an annualized 196 percent from March 2 to April 10. That trade produced a 41 percent annualized loss from September, when Lehman collapsed, through February. Benchmark rates in those seven economies range from 3 percent in New Zealand and Australia to Brazil's 11.25 percent. Comparable rates in the euro region, Japan and the US are $1.25,0.1$ and between zero and 0.25 percent, respectively". ${ }^{5}$

The experience of the last decade suggests that Chinese demand for primary commodities, external investment and the resumption of the carry trade imply leaving development strategy to the vagaries of foreign governments and international monetary conditions. Abandoning this policy would also simply recognize and increasingly voiced opinion that it is not possible for an economy to develop on the basis of external savings. ${ }^{6}$ On this view all development depends on the mobilization of domestic resources and the direction of domestic policy to achieve full utilization of domestic resources.

Thus, the most obvious path, and the continuing dilemma facing countries that have adopted a development strategy based on external demand is the transition to growth based on domestic income growth and domestic consumption through diversification of markets and production. Indeed, the shift from an export dependent economy to a domestic demand led economy has been a highly elusive goal. Japan has never been able to achieve it and has suffered from stagnant growth since 1999. But this is not an option for Brazil, since its per capita income level is not

\footnotetext{
${ }^{5}$ Kim-Mai Cutler \& Bo Nielsen, “Carry Trade Comeback Means Biggest Gains Since 1999 (Correct)”, April 14, 2009, http://www.bloomberg.com/apps/news?pid=newsarchive\&sid=aKbFuB4RIpQo.

${ }^{6}$ See Bresser-Pereira, Developing Brazil - Overcoming the Failure of the Washington Consensus, Boulder, CO: Lynne Rienner Publishers, 2009, and Kregel, "The Discrete Charm of the Washington Consensus," Journal of Post-Keynesian Economics, Volume 30, Number 4 / Summer 2008. This position simply reflects a tradition of the Development Pioneers such as Prebisch, Furtado, Nurkse, Myrdal and others. It is also present in the work of UNCTAD's Trade and Development Reports in the 1990s.
} 
near that of Japan and its population growth is far higher than in Japan. The same is true of the other BRIC economies. Thus, the key to the continuation of the dream is the transformation from export to domestic demand led growth in economies in which there is still a large peasant or agricultural population and the associated inequality in incomes.

From this point of view Brazil seems much better placed than the other BRICs. Indeed, Brazil already has a transition policy ready to be implemented. The basis is to be found in the Plano Plurianual 2004-2007 which was followed in 2006 in the Agenda Nacional Desenvolvmiento (AND) and then in the 2007 Programa de Aceleração do Crescimento (PAC) to augment the rate of domestic demand and growth through government supported infrastructure investment projects such as the rebuilding of houses and the construction of roads, many of which aim to improve the situation of disadvantaged members of Brazilian society. In a country known for its corruption and inefficient bureaucracy, one must question whether these programs sufficiently address the root causes of the social problems they intend to tackle. It also remains to be seen whether they generate lasting social change that will last far beyond Lula's time in office and beyond the present boom economy.

The basis of the PPA was to build on domestic demand by reducing income inequality and creating demand for products that could be produced by domestic industry with government support. It is precisely the kind of program that is required to shift the dependence from foreign to domestic demand without creating domestic inflation or external imbalances. The existence of a strong national development bank to finance the supply side of the program, and the ability to act on incomes through an increase in the minimum wage provides a balanced growth program that is perfectly suited to respond to the current crisis and to provide the basis for increasing growth in conditions of global recession.

On the demand side, the proposed increase in the renda basica is, however, an inefficient tool for building domestic demand and reducing inequality for it only has an impact on the employed while one of the greatest impacts of the crisis is the increase in unemployment in addition to the long-term deficiency of employment in Brasil. It would thus be necessary to accompany the implementation of the PPA with a well-designed program of government employment or job guarantees. India has already taken steps in this direction with its 2005 National Rural Employment Guarantee Act, ${ }^{7}$ and in Brazil the Programa Cidade Cidadã has been proposed for large urban areas. ${ }^{8}$ Such a policy might also reduce pressure on land distribution as it is reported the largest proportion of the members of Sem Terra groups seeking

\footnotetext{
${ }^{7}$ In this respect, and increase in the supply of jobs might reduce the pressure in the countryside, as it is reported that a large proportion of the supporters of the Sem Terra movement are unemployed urban workers who see agricultural employment as the only possibility to gain a decent living.

${ }^{8}$ See Instituto Desemprego Zero at www.desempregozero.org.br. More general information on job guarantee programs employed in other economies see www.economistsforfullemployment.org.
} 
a subsistence on the land are discouraged urban workers who have given up attempting to find industrial employment.

When the PPA was first introduced, and when the AND and the PAC were proposed they were never fully implemented because of external considerations surrounding the impact on government finances and the need to gain investment grade to deal with the problem of debt sustainability. Indeed, economic policy was itself designed in such a way to allow Brazil to benefit from the US demand led and Chinese financed growth of global trade and finance. If that global growth structure is no longer likely to be restored, then domestic policy can and should be changed to be compatible with the new global structure. The most important attractor will be the ability to grow domestically without the need for external demand and foreign financing within the bounds of international trade agreements. The PPA combined with a national jobs guarantee program would provide such a possibility. In addition, it will be necessary to transform the domestic financial market from an institution to provide government financing to one that provides long-term capital for domestic productive investment.

From this perspective Brazil has an advantage over the other BRIC countries, including China, given its existing structures to support research and development and the possibility to provide a balanced expansion based on industry and development of natural resources and agriculture. It also has a banking system that can develop a capital market that could complement the activity of BNDES which could concentrate on support of new areas of technology growth. If Brazil can wean itself from dependence on external demand and external finance by implementing a sustainable transition to domestic demand led growth it will remain a solid BRIC.

While Brazil is especially well placed to implement a transition policy from external to internal demand led growth it must be recognized that if all emerging market developing countries were to successfully make this transition it would once again create pressure on primary commodity supplies and energy prices, as well as exacerbating environmental issues. Thus, domestic demand led policies must also include attention to food and environmental issues which have a disproportionate impact on price stability and on incomes in the poorest countries. 